\title{
Hubungan anemia dengan kualitas hidup pasien penyakit ginjal kronik yang sedang menjalani hemodialisis reguler
}

\author{
${ }^{1}$ Cindy R. Senduk \\ ${ }^{2}$ Stella Palar \\ ${ }^{2}$ Linda W. A. Rotty \\ ${ }^{1}$ Kandidat Skripsi Fakultas Kedokteran Universitas Sam Ratulangi Manado \\ ${ }^{2}$ Bagian Ilmu Penyakit Dalam RSUP Prof.dr. R. D. Kandou Manado \\ Email: cindyreginas@yahoo.com
}

\begin{abstract}
The objective of this study is to determine the correlation between anemia and quality of life in chronic kidney disease patients undergoing regular hemodialysis. This was an observational analytical study with a cross-sectional design. Samples were obtained by using consecutive sampling. Patients' quality of life was assessed with short-form 36 questionnaires (SF-36) while their Hb levels data were taken from the medical records. There were 60 samples, with a majority age range of 50-59 years old (33.33\%) adn the dominant gender was males (68,3\%). There were 13 non-anemia patients (22\%), 27 mild anemia patients $(45.0 \%)$, 15 moderate anemia patients (25.0\%) and 5 severe anemia patients (8\%). The highest quality of life score obtained was 90.70 with an average score 61.99. The Spearman correlation test showed a correlation between anemia and life quality $(\mathrm{p}=0.000)$. Conclusion: There was a significant correlation between anemia and quality of life in chronic kidney disease patients undergoing regular hemodialysis.
\end{abstract}

Keywords: chronic kidney disease, hemodialysis, anemia, quality of life

\begin{abstract}
Abstrak: Tujuan dari penelitian ini untuk mengetahui hubungan anemia dengan kualitas hidup pasien PGK yang sedang menjalani hemodialisis reguler. Desain penelitian yang digunakan adalah analitik observasional dengan rancangan studi potong silang (cross sectional study). Teknik pengambilan sampel yang digunakan yaitu consecutive sampling. Data kualitas hidup pasien diukur dengan pertanyaan dalam kuesioner Short Form (SF-36) sedangkan kadar Hb diambil dari rekam medik. Hasil dari penelitian ini didapatkan sampel 60 orang, usia terbanyak 50-59 tahun (33,3\%), jenis kelamin terbanyak adalah laki-laki $(68,3 \%)$, tidak anemia 13 orang (22\%), anemia ringan 27 orang (45,0\%), 15 orang (25,0\%) anemia sedang dan sisanya 5 orang (8\%) anemia berat. Skor kualitas hidup tertinggi 90,70 dengan rata-rata 61,99. Uji korelasi spearman didapatkan hubungan antara anemia dengan kualitas hidup $(\mathrm{p}=0,000)$. Simpulan: Terdapat hubungan yang signifikan antara anemia dengan kualitas hidup pasien PGK yang sedang menjalani hemodialisis reguler.
\end{abstract}

Kata kunci: penyakit ginjal kronik, hemodialisis, anemia, kualitas hidup

Penyakit Ginjal Kronik (PGK) merupakan salah satu masalah kesehatan dunia yang penting saat ini. Menurut United State Renal Data System prevalensi penyakit ginjal kronik di dunia meningkat 20-25\% setiap tahun, sehingga diperkirakan 1 dari 10 orang di dunia memiliki PGK. ${ }^{1}$ Menurut laporan Indonesian Renal Registry (2012) pada tahun 2009, tercatat sebanyak 5.450 pasien gagal ginjal yang menjalani hemodialisis, meningkat pada tahun 2010 sebanyak 8.034 penderita dan meningkat lagi pada tahun 2011 sebanyak 12.804 penderita. World Health Organization 
memperkirakan di Indonesia akan terjadi peningkatan pasien PGK pada tahun 19952025 sebesar 41,4\% dan menurut data dari Persatuan Nefrologi Indonesia (Pernefri) diperkirakan terdapat 70.000 pasien penyakit ginjal di Indonesia, angka ini akan terus meningkat sekitar $10 \%$ setiap tahunnya. $^{2}$

Penyakit Ginjal Kronik adalah setiap kerusakan ginjal (kidney damage) atau penurunan laju filtrasi glomerulus (LFG/GFR/Glomerular Filtration Rate) $<60 \mathrm{ml} / \mathrm{menit} / 1,73 \mathrm{~m}^{2}$ untuk jangka waktu $\geq 3$ bulan. $^{2}$ Penyakit Ginjal Kronik mengakibatkan penurunan fungsi ginjal yang progresif dan irreversible sehingga memerlukan terapi pengganti ginjal yang tetap, berupa dialisis atau transplantasi ginjal. $^{3}$ Hemodialisis merupakan terapi pengganti ginjal yang bertujuan mengembalikan keadaan cairan intrasel dan ekstrasel ke keadaan normal dengan cara membuang limbah metabolik dan kelebihan cairan tubuh melalui darah. ${ }^{2}$

Anemia merupakan salah satu komplikasi pada PGK yang sering terjadi. Anemia terjadi pada $80-90 \%$ pasien PGK. ${ }^{4}$ Secara fungsional anemia didefinisikan sebagai penurunan jumlah masa eritrosit, sehingga tidak dapat memenuhi fungsinya untuk membawa oksigen dalam jumlah cukup ke jaringan perifer. Etiologi Anemia pada keadaan PGK merupakan kelainan multifaktorial dan defisiensi erythropoietic stimulating factors (ESF). ${ }^{4}$ Pasien dengan anemia berat dan berlangsung lama memperlihatkan kelelahan mental dan fisik, penurunan kapasitas latihan, gangguan fungsi kognitif, penurunan libido dan fungsi seksual, dan nafsu makan hilang sehingga dapat mempengaruhi kualitas hidup pasien. ${ }^{4}$ Anemia berperan dalam meningkatnya morbiditas dan mortalitas, rendahnya kualitas hidup pada pasien PGK serta mempercepat progres pasien menuju gagal ginjal terminal. ${ }^{5-7}$

Goodinson dan Singleton (O’Connor, 1993) mengemukakan definisi kualitas hidup sebagai derajat kepuasan atas penerimaan suasana kehidupan saat ini. ${ }^{8}$ Penilaian kualitas hidup menentukan seberapa dekat modalitas terapi dalam memperpanjang hidup, menghilangkan tekanan, mengembalikan fungsi dan mencegah disabilitas, yang secara konsekuen akan menyebabkan hidup yang lebih produktif dan efektif. ${ }^{8}$ Penilaian kualitas hidup pada pasien yang mengalami anemia pada saat hemodialisis perlu dilakukan sebagai prediktor mortalitas.

Penelitian ini dilakukan untuk mengetahui hubungan anemia dengan kualitas hidup pasien PGK yang sedang menjalani hemodialisis regular.

\section{METODE PENELITIAN}

Desain Penelitian bersifat observasional analitik dengan rancangan potong lintang. Penelitian ini dilaksanakan di Instalasi Tindakan Khusus (ITK) Hemodialisis RSUP Prof. dr. R.D. Kandou Manado dalam jangka waktu 3 bulan yaitu pada Oktober - Desember 2015. Populasi penelitian ini ialah pasien PGK. Populasi terjangkau ialah pasien PGK dengan anemia yang sedang menjalani hemodialisis regular. Sampel penelitian ini ialah pasien PGK dengan anemia yang sedang menjalani hemodialisis reguler yang memenuhi kriteria inklusi dan eksklusi.

Kriteria Inklusi ialah pasien PGK yang sedang menjalani hemodialisis reguler rawat jalan, usia $>18$ tahun, $\mathrm{Hb}<12 \mathrm{gr} / \mathrm{dL}$, bersedia mengikuti penelitian dan menanda-tangani surat persetujuan (informed consent) atas dasar sukarela. Kriteria Eksklusi dalam penelitian ialah pasien PGK yang sedang menjalani hemodialisis reguler rawat inap, pasien PGK yang sedang menjalani hemodialisis reguler dengan hepatitis virus, pasien PGK dengan hipertensi yang belum terkontrol (TD >140/90mmHg). Variabel penelitian terdiri dari variable bebas yaitu anemia dan variable tergantung yaitu kualitas hidup. Anemia pada PGK jika $\$ \mathrm{~b} 10 \mathrm{gr} / \mathrm{dl}$.

Pembagian derajat anemia berdasarkan WHO yaitu anemia ringan : konsentrasi $\mathrm{Hb}$ kurang dari 8,0g/dL-9,9g/dL, anemia sedang: konsentrasi $\mathrm{Hb}$ kurang dari 6,0g/dL-7,9g/dL, anemia berat: konsentrasi $\mathrm{Hb}$ kurang dari 6,0g/dL, non-anemia: 
konsentrasi $\mathrm{Hb}$ lebih dari $10 \mathrm{~g} / \mathrm{dl}$. Pengambilan sampel dalam penelitian ini yaitu mengambil subjek pasien PGK rawat jalan yang sedang menjalani hemodialisis reguler di ITK Hemodialisis RSUP Prof. dr. R. D. Kandou Manado secara berurutan (consecutive sampling) berdasarkan kriteria inklusi hingga jumlah sampel yang dikehendaki terpenuhi. Semua peserta penelitian menjalani pemeriksaan berupa anamnesis dan pemeriksaan fisik, sedangkan pengumpulan data kadar $\mathrm{Hb}$ pasien dilakukan dengan melihat catatan rekam medik pasien. Data kualitas hidup pasien diukur dengan skor pertanyaan dalam kuesioner short form (SF-36). Analisis data untuk menentukan hubungan anemia dengan kualitas hidup dilakukan dengan analisis bivariat spearman's correlation sedangkan hasil analisis data untuk menentukan perbedaan kualitas hidup antar derajat anemia digunakan uji Kruskal-Wallis.

\section{HASIL PENELITIAN}

Penelitian ini dilakukan di Instalasi Tindakan Khusus Hemodialisis RSUP Prof.R.D.Kandou Manado dalam jangka waktu 3 bulan yaitu Oktober - Desember 2015. Subyek penelitian sebanyak 60 orang responden yang memenuhi kriteria inklusi. Responden diukur tingkat kualitas hidupnya dengan mengisi kuesioner Short form 36.

\section{Distribusi responden berdasarkan jenis kelamin}

Dari 60 responden, didapatkan bahwa 41 orang $(68,3 \%)$ berjenis kelamin lakilaki, sedangkan sisanya yaitu 19 orang (31,7\%) berjenis kelamin perempuan

Tabel 1. Distribusi responden berdasarkan jenis kelamin

\begin{tabular}{lcc}
\hline & Frekuensi & $\%$ \\
\hline Laki - laki & 41 & $68,3 \%$ \\
Perempuan & 19 & $31,7 \%$ \\
\hline Total & 60 & $100 \%$ \\
\hline
\end{tabular}

Distribusi responden berdasarkan usia

Pada penelitian ini didapatkan jumlah responden yang berusia 30-39 tahun adalah 6 orang (10\%), responden yang berusia 40 49 adalah 13 orang $(21,7 \%)$, yang berusia 50-59 tahun 20 orang (33,3\%), yang berusia 60-69 tahun sebanyak 14 orang (23,3\%), yang berusia $70-79$ tahun 6 orang (10\%) dan responden yang berusia 80-89 tahun 1 orang (1,7\%). Berdasarkan Gambar 1. dapat dilihat bahwa kelompok usia yang paling banyak adalah kelompok usia 50-59 tahun.

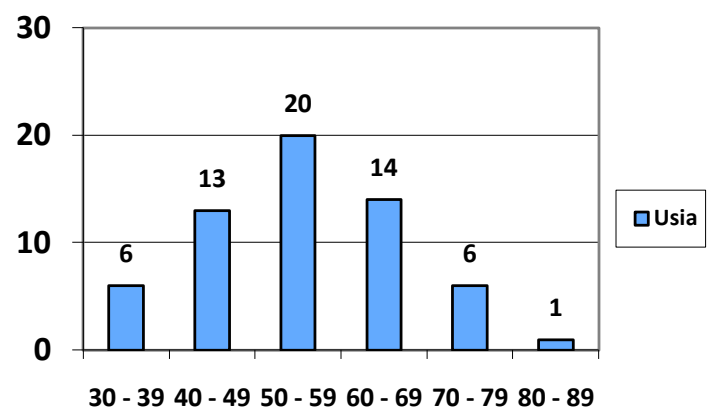

Gambar 1. Distribusi Responden berdasarkan Usia

\section{Distribusi responden berdasarkan} derajat anemia

Dari 60 responden, didapatkan bahwa 13 orang (22\%) termasuk dalam kategori non anemia, responden dengan anemia ringan sebanyak 27 orang (45\%), anemia sedang sebanyak 15 orang (25\%) dan sisanya 5 orang (8\%) termasuk dalam kategori anemia berat.

\section{Distribusi Nilai Kualitas Hidup} Responden berdasarkan Derajat Anemia

Jumlah responden yang termasuk dalam kategori non anemia yaitu 13 orang dengan skor kualitas hidup tertinggi 90,70 dengan rata-rata 72,7069 serta nilai simpang baku 13,43118. Untuk anemia ringan sebanyak 27 orang dengan skor tertinggi 88,60 dengan rata-rata 64,2370 serta nilai simpang baku 16,50553. Anemia sedang sebanyak 15 orang dengan skor tertinggi 86,0 dengan rata-rata 53,9933 serta nilai simpang baku 17,04022 dan sisanya 5 orang termasuk dalam kategori 
anemia berat dengan skor tertinggi 58,0 dan nilai rata-rata 46,0200 serta nilai simpang baku 11,75530.

Tabel 2. Distribusi responden berdasarkan derajat anemia

\begin{tabular}{lcc}
\hline & Frekuensi & Persentase \\
\hline Non Anemia & 13 & $22 \%$ \\
Anemia Ringan & 27 & $45 \%$ \\
Anemia Sedang & 15 & $25 \%$ \\
Anemia Berat & 5 & $8 \%$ \\
\hline Total & 60 & $100 \%$ \\
\hline
\end{tabular}

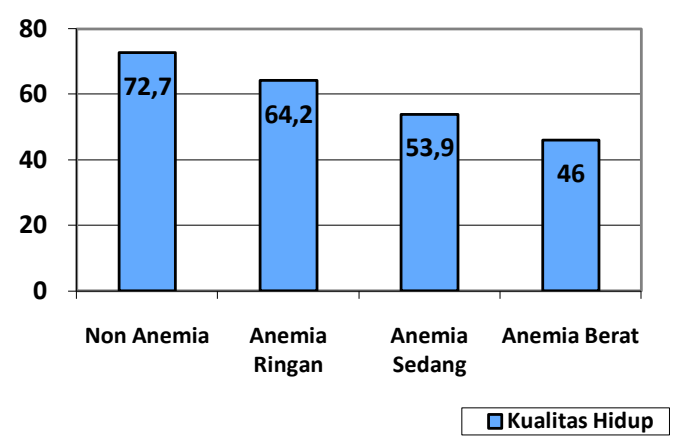

Gambar 2. Nilai Rerata Kualitas Hidup berdasarkan Derajat Anemia

\section{Karakteristik Kualitas Hidup Responden dinilai dengan Kuesioner SF- 36}

Berdasarkan penilaian 8 skala kualitas hidup didapatkan bahwa sebagian skala mempunyai rata-rata nilai diatas nilai normal, yaitu skala rasa sakit, fungsi sosial, keterbatasan emosi dan kesehatan mental. Sedangkan 4 skala mempunyai nilai ratarata dibawah nilai normal yaitu skala fungsi fisik, keterbatasan fisik, kesehatan umum dan vitalitas.

\section{Analisis Perbedaan Kualitas Hidup (QOL) antar-Anemia \\ Pada uji Kruskal-Wallis didapatkan nilai $\mathrm{p}=0,007(\mathrm{p}<0,05)$ maka dapat diambil kesimpulan bahwa terdapat perbedaan bermakna terhadap kualitas hidup pada derajat anemia.}

\section{Analisis Hubungan Anemia dengan Kualitas Hidup pasien PGK}

Untuk mengetahui adanya hubungan anemia dengan kualitas hidup digunakan analisis bivariat spearman's correlation. Pada penelitian ini didapatkan nilai $\mathrm{p}=$ 0,000 ( $\mathrm{p}<0,05$ ) yang menandakan ada hubungan yang bermakna dengan kekuatan hubungan $r=-0,452$ (sedang). Arah hubungan adalah negatif.

\section{BAHASAN}

Pada penelitian ini didapatkan jumlah sampel 60 pasien terdiri atas 41 orang lakilaki dan 19 orang perempuan dengan kelompok usia tertinggi pada usia 50-59 tahun. Hal ini sejalan dengan data dari Indonesian Renal Registry 2012 yaitu jumlah pasien laki-laki, tiap tahun melebihi jumlah pasien perempuan dan distribusi usia pasien terbanyak ada pada kelompok usia 45-54 tahun.

Ginjal merupakan organ vital bagi tubuh yang berfungsi dalam mengekskresikan produk sisa metabolisme, mempertahankan keseimbangan cairan dan elektrolit darah, mensekresikan eritropoietin untuk merangsang produksi eritrosit serta mensintesis vitamin D. ${ }^{9}$ Namun pada usia yang berkisar antara 40 sampai 80 tahun terjadi penurunan fungsi ginjal yang terjadi akibat perubahan baik secara anatomis maupun fisiologis, diantaranya penurunan massa ginjal hingga $20 \%$, membran filtrasi yang berubah menjadi semakin permeabel serta tubulus ginjal secara bertahap mengalami degenerasi dan digantikan dengan jaringan ikat. Selain itu juga terjadi perubahan secara fisiologis yaitu ketidakseimbangan elektrolit, berkurangnya klirens kreatinin serta berkurangnya metabolit. ${ }^{10}$ Hal inilah yang menyebabkan pasien yang mengalami PGK sebagian besar adalah pasien dengan rentang usia 50-59 tahun. Namun, tidak hanya proses penuaan yang menyebabkan penurunan fungsi pada ginjal, hal ini juga bisa terjadi pada usia muda yang disebabkan oleh faktor-faktor lain yang merupakan faktor resiko terjadinya PGK yaitu gaya hidup, adanya penyakit ginjal, riwayat penyakit keluarga seperti diabetes melitus, hipertensi dan gagal ginjal. ${ }^{4}$ Berdasarkan penelitian yang dilakukan Astrini (2013) ${ }^{11}$ insiden PGK lebih tinggi 
pada laki-laki dibandingkan dengan perempuan. Hal ini dapat dihubungkan dengan faktor resiko seperti kebiasaan merokok, konsumsi alkohol, hipertensi dan diabetes mellitus. ${ }^{12}$

Berdasarkan penilaian derajat anemia didapatkan bahwa jumlah responden yang termasuk dalam kategori non anemia yaitu 13 orang (22\%), anemia ringan sebanyak 27 orang (45,0\%), 15 orang (25,0\%) dengan anemia sedang dan sisanya 5 orang (8\%) termasuk dalam kategori anemia berat. Anemia terjadi pada $80-90 \%$ pasien penyakit ginjal kronik. ${ }^{4}$ Faktor utama yang sering menyebabkan anemia pada pasien yang sedang menjalani HD, yaitu defisiensi eritropoetin. Faktor kehilangan darah yang banyak, seperti flebotomi berulang untuk pemeriksaan laboratorium dan retensi darah pada dialiser juga merupakan salah satu penyebab anemia pada pasien PGK. Selain itu anemia pada PGK disebabkan karena kurangnya asupan makanan yang mengandung besi. ${ }^{13}$ Oleh karena itu pemberian suplementasi terapi zat besi penting untuk diberikan untuk mencegah defisiensi zat besi. ${ }^{6}$

Hasil analisa statistik deskriptif terhadap delapan skala kualitas hidup yang diukur menggunakan kuesioner SF-36 menunjukkan terjadinya penurunan pada sebagian skala yaitu skala fungsi fisik, keterbatasan fisik, kesehatan umum dan vitalitas sedangkan skala rasa sakit, fungsi sosial, keterbatasan emosi dan kesehatan mental mempunyai nilai rata-rata diatas rata-rata nilai normal. Hal ini sejalan dengan penelitian yang dilakukan oleh Anees (2011) ${ }^{14}$ yaitu pasien HD di Pakistan memiliki kualitas hidup yang kurang baik dilihat dari penurunan aspek fisik, psikologis, maupun sosial dan lingkungan. ${ }^{14}$

Hasil penelitian di Instalasi Tindakan Khusus Hemodialisa RSUP Prof.R.D.Kandou Manado selama selang waktu Oktober 2015 - Desember 2015 didapatkan bahwa terdapat perbedaan kualitas hidup antar derajat anemia, dengan $\mathrm{p}$ value $=0,07$. Dari hasil tersebut maka didapatkan bahwa semakin berat anemia maka kualitas hidup semakin menurun. Pada penelitian ini juga didapatkan hasil uji Spearman bahwa anemia berhubungan dengan kualitas hidup, dengan $\mathrm{p}$ value $=$ 0,00; hal ini sesuai dengan kepustakaan yang menyatakan bahwa anemia yang terjadi pada pasien PGK yang sedang menjalani hemodialisa dapat menyebabkan penurunan kualitas hidup serta meningkatkan mortalitas, hal ini disebabkan karena anemia dapat menyebabkan kelelahan, berkurangnya kapasitas latihan akibat kurangnya oksigen yang dibawa ke jaringan tubuh, gangguan imunitas, kemampuan kognitif berkurang. ${ }^{15}$ Finklestein et al (2009) ${ }^{6}$ melakukan penelitian tentang hubungan kadar $\mathrm{Hb}$ dengan kualitas hidup menggunakan kuesioner SF-36 yang dilakukan terhadap 1200 responden dan didapatkan hasil bahwa kadar $\mathrm{Hb}$ berhubungan dengan total skor dari kuesioner SF-36. Pada penelitian ini juga didapatkan hasil bahwa peningkatan kadar $\mathrm{Hb}$ dapat meningkatkan secara signifikan kualitas hidup dimensi kesehatan fisik dan kesehatan secara umum. Penelitian yang lain juga mendukung dilakukan oleh Astrini (2013) ${ }^{11}$ yang mendapatkan hasil bahwa kadar $\mathrm{Hb}$ berhubungan dengan kualitas hidup.

Hasil yang berbeda didapatkan oleh Nurchyati $(2010)^{16}$ pada penelitian yang dilakukan pada 95 responden untuk menilai hubungan kadar $\mathrm{Hb}$ dengan kualitas hidup dan didapatkan hasil bahwa kadar Hb tidak berhubungan dengan kualitas hidup. Hasil tersebut sejalan dengan penelitian Ayoub et al $(2014)^{17}$ yang melakukan penelitian tentang hubungan kadar $\mathrm{Hb}$ dengan kualitas hidup menggunakan kuesioner SF-36 pada 130 responden, dan mendapatkan hasil yaitu kadar $\mathrm{Hb}$ tidak berhubungan dengan total skor dari kuesioner SF-36.

\section{SIMPULAN DAN SARAN}

Berdasarkan hasil penelitian dan bahasan dapat disimpulkan bahwa terdapat hubungan bermakna antara anemia dengan kualitas hidup pasien PGK yang sedang menjalani hemodialisis regular. Juga terdapat perbedaan kualitas hidup antar 
Senduk, Palar, Rotty: Hubungan anemia dengan...

derajat anemia pada pasien PGK yang sedang menjalani hemodialisis regular.

\section{SARAN}

Dengan memahami hubungan anemia sebagai faktor yang menentukan kualitas hidup pasien PGK yang sedang menjalani hemodialisis reguler maka diharapkan untuk dapat menangani anemia pada pasien PGK secara maksimal. Perlu juga dilakukan penelitian serupa untuk menilai pengaruh faktor-faktor lain terhadap kualitas hidup pasien PGK yang sedang menjalani hemodialisis reguler.

\section{DAFTAR PUSTAKA}

1. The United States Renal Data System. Incidence, prevalence, patient characteristics and treatment modality. [internet] cited 23 september 2015. Available from: http//www.usrds.org/.

2. Suwitra K. Penyakit Ginjal Kronik. Dalam: Sudoyo AW, Setiyohadi B, Alwi I, Simadibrata M, Setiati S, editor. Buku Ajar Ilmu Penyakit Dalam Jilid III Edisi V. Jakarta: Interna Publishing. 2009.

3. Adiatma DC, Tobing ML. Prevalensi dan Jenis Anemia pada Pasien Penyakit Ginjal Kronik yang menjalani Hemodialisis Reguler. Semarang: Eprints Universitas Diponegoro; 2014.

4. Sukandar E. Nefrologi Klinik. Edisi IV. Bandung: IPEDE; 2013.h. 802-6.

5. Farag YM, Keithi-Reddy SR, Mittal BV, et al. Anemia, inflammation and health-related quality of life in chronic kidney disease patients. Clin Nephrol. 2011;75:524-533.

6. Finkelstein FO, Story K, Firanek C, et al. Health-related quality of life and hemoglobin levels in chronic kidney disease patients. Clin J Am Soc Nephrol. 2009;4:33-38.

7. Voormolen N, Grootendorst DC, Urlings TA, et al. Prevalence of Anemia and its impact on mortality and hospitalization rate in predialysis patients. Nephron Clin Pract. 2010;115:c133-c141.

8. Supriyadi, Wagiyo, Widowati. Tingkat Kualitas Hidup Pasien Gagal Ginjal Kronik Terapi Hemodialisis. Journal Kemas. 2011;6:107-112.

9. Kumar. Buku Ajar Patologi. Jakarta:EGC. 2007.

10.Andrade $\mathbf{M}$, John $\mathbf{K}$. Exploring the Anatomy and Physiology of Ageing. Part 4: The Renal System. 2008;104(34): 22-23.

11.Astrini, Hasibuan P, Irsan A. Hubungan Kadar Hemoglobin, Indeks Massa Tubuh dan Tekanan Darah dengan Kualitas Hidup pasien Gagal Ginjal Kronik yang menjalani hemodialisis di RSUD DR SOEDARSO PONTIANAK [skripsi]. Pontianak: Universitas Tanjungpura; 2013.

12.Iseki K. Gender Differences in Chronic Kidney Disease. Kidney Int. 2008;74(4):415-7.

13.Bakta IM. Pendekatan Terhadap Pasien Anemia. Dalam: Sudoyo AW, Setiyohadi B, Alwi I, Simadibrata M, Setiati S, editor. Buku Ajar Ilmu Penyakit Dalam Jilid III Edisi V. Jakarta: Interna Publishing. 2009: 1109-1115.

14.Anees. Dialysis-Related Factors Affecting Quality of Life in Patients on Hemodialysis. IJKP. 2011;5(1):9-14.

15.Clement FM, Klarenbach S, Tonelli $\mathbf{M}$ et al. The impact of selecting high hemoglobin target level on health related quality of life for patients with chronic kidney disease. Arch Intern Med. 2009;169:1104-1112.

16.Nurchayati S. Analisis faktor-faktor yang berhubungan dengan Kualitas Hidup pasien Penyakit Ginjal di rumah sakit Islam Fatimah Cilacap [thesis]. Depok: Universitas Indonesia; 2010.

17.Ayoub A, Nelson K, Hijjazi. The Relationship between laboratory values and quality of life of dialysis patients in the United Arab Emirates. Renal Society of Australasia Journal. 2014;10(1):12-20. 